\title{
The Relationship between Human Resources Management Activities and the Practice of Strategic Planning in Saudi Banks
}

\author{
Mohammed S. Al-Amri ${ }^{1}$, Abdullah R. Almeshhen ${ }^{2} \&$ Mohammed Z. Alothman ${ }^{3}$ \\ ${ }^{1}$ Department of Management, College of Business Administration, King Saud University, Riyadh, Saudi Arabia \\ ${ }^{2}$ Human Resources Department, Al-Rajhi Bank, Riyadh, Saudi Arabia \\ ${ }^{3}$ Quality Management and Excellence Unit, Saudi Investment Bank, Riyadh, Saudi Arabia \\ Correspondence: Mohammed S. Al-Amri, Department of Management, College of Business Administration, King \\ Saud University, Riyadh, Saudi Arabia.
}

Received: October 24, 2016

Accepted: November 8, 2016

Online Published: November 12, 2016

doi:10.5430/ijba.v7n6p57

URL: http://dx.doi.org/10.5430/ijba.v7n6p57

\begin{abstract}
The aim of this study is to examine the relationship between human resources management activities and strategic planning in Saudi Banks. To achieve this aim, the study utilized a questionnaire consists of two validated, well established instruments: the first one is the human resources management activities scale developed by Al-Domour (2008) and includes 34-items that measures an all senior level employees in human resources departments in major banks in Saudi Arabia on the human resources management activities, the second instrument called practice of strategic planning scale developed by Al-Domour (2008) and includes 6-items to identify practice of strategic planning. This questionnaire has been distributed to a sample consist of (265) senior level employees of those banks. A total of (200) complete questionnaires has been received back at a response rate of $75 \%$. After analysing data and testing hypotheses, the study revealed a there is a positive relation between human resources management activities (job analysis, human resources planning, recruitment, selection, training and development, motivation, and performance management) and practice of strategic planning. The study also revealed that there are no statistically significant differences in the response of the respondents on the human resources management activities due to personal characteristics (gender, age, educational qualification, Job title, and years of experience). Based on these results, certain recommendations were suggested.
\end{abstract}

Keywords: strategic planning, job analysis, recruitment, selection, training and development, performance management, human resources planning, motivation and Saudi Arabia banks

\section{Introduction}

In recent years, the concepts of strategic planning has gained wide attention in the research literature for both managers and academicians in both public and private sector organisations (e.g. Bryson, 2010; Jehads and Naseem, 2011; Ieva, Roman, and Tatjana, 2012; Dessler, 2015). It is important to managers in general because one of the most essential elements of organization, which should properly be management, is strategic planning. No organization can ever survive anywhere or at any time without focusing on their strategic planning.

The strategic planning has emerged as a topic of interest in management studies. There have been numerous articles concerning this term, but there are relatively few which study the relationship between human resources management activities and strategic planning.

It is worth noting that whereas human resources management in particular and strategic planning have been studied in the western context only a few studies have been conducted in developing countries and especially in Arab countries.

Indeed, human resources management and strategic planning have been a matter of growing interest for those concerned with the success of an organisation and achievement of its objectives, the quality of working life, efficiency, productivity, and turnover.

The researcher's expectation that human resources management activities has a relationship with strategic planning results from the research literature, which suggests strategic planning is thereby an important task that every 
company must undertake in order to oversee elements such as employments, benefits, challenges and performances of an organization.

In this study, the human resources management activities of employees are examined to investigate its relationship with strategic planning in the banking sector at Saudi Arabia.

\subsection{Statement of the Problem}

Strategic planning is one of the main new managerial concept that have effective tools to achieve the long term goals. However, it will measure the current and future capabilities that will assure the success of the organization in this competitive world. Therefore, the problem of the study is to identify the relationship between human resources management activities and the practice of strategic planning of human resources department in Saudi Banks. It is also try to investigate the most significant problem that banking sector face during their implementation of strategic planning.

\subsection{The Purposes of the Study}

- The concept of strategic planning has been manifested to have influence in human resource management activities within the firm. Strategic planning helps in the provision of the overall strategic directions to those areas as the human resource managements in ensuring the firm reaches its stipulated goals. This study will thereby identify or establish the reality of the relationship between human resource management activities and practice of strategic planning of Saudi Banks.

- The findings of this study may contribute to more improvement in the quality of work in Saudi banks. Due to the lack of studies in this field, the recommendations of this study may be a stimulus for researchers to focus their future researches on this vital area.

- As such, the research will be essential for the banks' human resource management departments in their policy formulations and strategic plans for their bank's performance and success.

\subsection{The Objectives of the Study}

- Provide an appropriate theoretical framework that illustrates human resource management activities and strategic planning

- Evidence indicates that strategic planning can influence work related behaviour. However, there is no research which attempts to relate human resource management activities and strategic planning in Saudi Arabia. This study considers whether there is any relation between the human resource management activities and strategic planning.

- It will fill a gap in the research literature on human resource management activities and strategic planning.

- It is also expected that the result of this study will inform the decision makers in Saudi Arabia about the extent of human resource management activities and strategic planning among employees within the Saudi banks. It also could be of value to the Chamber of Commerce, (the major private agency entrusted with the supervision on Saudi private companies) to better understand human behavior and hence be better able to make recommendations for improving productivity.

- Present proper and effective recommendations to both academicians and human resource practitioners, which will aim at creating in-depth awareness on the realities of the relationship between human resources management activities and Saudi banks' strategic planning.

\subsection{Study Hypotheses}

There are two main hypotheses in this study:

$\mathbf{H}_{1}$ : There is no statistically significant correlation between human resources management activities and the practice of strategic planning in Saudi banks. There are sub hypotheses under this hypothesis:

$\mathbf{H}_{1-1}$ : There is no statistically significant correlation between job analysis and the practice of strategic planning in the human resource departments at Saudi banks.

$\mathrm{H}_{1-2}$ : There is no statistically significant correlation between human resource planning and the practice of strategic planning in the human resource departments at Saudi banks.

$\mathrm{H}_{1-3}$ : There is no statistically significant correlation between recruitment and the practice of strategic planning in the human resource departments at Saudi banks. 
$\mathrm{H}_{1-4}$ : There is no statistically significant correlation between selection and the practice of strategic planning in the human resource departments at Saudi banks.

$\mathrm{H}_{1-5}$ : There is no statistically significant correlation between training and development and the practice of strategic planning in the human resource departments at Saudi banks.

$\mathrm{H}_{1-6}$ : There is no statistically significant correlation between motivation and the practice of strategic planning in the human resource departments at Saudi banks.

$\mathrm{H}_{1-7}$ : There is no statistically significant correlation between performance management and the practice of strategic planning in the human resource departments at Saudi banks.

$\mathbf{H}_{2}$ : There are no statistically significant differences in the response of the respondents on the impact of human resources management activities on the practice of strategic planning due to personal characteristics (gender, age, educational qualification, job title, and years of experience).

\section{Theoretical Background and Literature Review}

\subsection{Theoretical Background}

Human resources are the foundations for all activities within an organization, any rule, strategy or force introduced by a strategic plan is likely to impact the entire organization's performance. A strategic plan must thereby be in line with the prevailing internal and external environments, organizational goals, and performance strategies in order to support the human-resource-related activities (Narasimha, 2000). This must also be relevantly supported by the modern technologies in the pursuit of competitiveness and organizational success.

Sims (2002) explained that human resource management entails employee related activities within an organization. Therefore, it is vital for the managers to ensure all the workers are fairly paid and that they work in the desired working environment. Some of the prominent activities that human resource management will carry out entail job analysis, human resource planning, human resource recruitment, selection of human resource, training and development of human resource, and performance management.

Job analysis: this activity is interested in selecting and hiring the candidates. It entails the development of job description a factor that outlines various skills possesses by the candidates (Laursen and Foss, 2003). The human resource manager then designs an advert of the job descriptions on the social media like the newspaper. The interview helps in weeding out those applicants that are not fit for the job. Ideas, job analysis assist in evaluating the workers' ability to perform.

Human resource planning: this is also one of the activities that an human resource manager should put into check. Human resource allocation connects the organizations needs and its human resource to the strategic plans so as to ensure that staffing is sufficient, competent enough, and are qualified (Martell and Carroll, 2005). This factor is geared by the intention towards achieving the firm's goals. Over the past years, human resource planning has become a crucial element of the organization towards attaining competitive advantage and hence helps in reduction of the employees turn over (Storey et al., 2002). Good human resource allocation helps the employees to enjoy their jobs and hence increases their chances of remaining in the same job for years. Human resource planning helps in tracking the high performers within the firm and hence rewarding them accordingly. Through the human resource planning, a firm may tell which human personnel are required to attain a given or specified business objectives.

Recruitment: it is evident that those companies that are up to the talented employees and cannot access them locally have gone overboard to look for the desired human resources in other nations or corporations. This factor calls for the importation of the labor from the foreign countries that in turn provide them with the international revenue (Martell and Carroll, 2005). It is vital for the managers to have an outstanding strategy while in the attempt of selling some employees. This aspect is important since if not well analyze with the incorporation of effective strategy then the company may suffer a great loss. Before the manager makes the decision on selling a given employee, variables on the workers' productivity should be analyzed as well as the number of employees in the affected department. This phenomenon can as well take place from within the firm when employees show a competent ability and, therefore, needs promotion (Storey et al., 2002). Likewise, the strategic planning plays a bigger role in merging workers here as well.

Selection of human resources: this aspect is very crucial in an organization since it helps in searching and obtaining the best possible candidate with the appropriate skills and experience that is required to meet the company's goals. Selection process helps in identification of a pool of employees by including avenues that are not limited to interviewing, testing, and reference checking. It is an exercise that must comply with fair and equitable activities. 
Most importantly, to select a desirable candidate, the appropriate strategy must be put in place. Having an effective recruitment strategy is vital for any organizations performance and future. Selection of the human resource may become so costly and ineffective if appropriate strategy is not inculcated and given a proactive approach (Scott and Bruce, 2004). Proper selection of the human resource will;

- Ensure the firm possess a viable learning resource and is able to meet the future objectives.

- Foster the supply and demand in the competitive global.

- Foster the buildup of competent employees.

- Enhances the evaluation stages by giving further examinations to those individuals that meets the desirable qualities.

Training and development of human resources: training is crucial in ensuring that human resources help in realizing the firm's objective. Training indeed boosts the productivity of each and every employee to greater heights. Training may take a form of handing out those manual forms that possess the company's policies and information to the workers so that they equip themselves to the ethical standards of business (Storey et al., 2002). On site training through the human resources, managers are also advantageous to the firm. Training has been seen to have increased the skills of many workers in using the computer software. Ideally, training helps in boosting the ability of employees to execute a given duty (Martell and Carroll, 2005).

Motivation: inspiration is the premise of practices and activities that individuals convey inside the relationship about the characteristic of the difficulties that take after a category or another of utilitarian relations (Niehaus et al., 2013). Along these lines, to guarantee the execution of the cutting edge relationship there is the need to know and comprehend the components that motivate or demotivate a worker and much more, to apply them. Individual and constructional execution are in direct association with the immediate performance of the administration of human resource. Along these lines, just by knowing the motivational speculations and by applying productive managerial procedures, keeping in mind the end goal to connect with the workers in the aggressive accomplishment of the association's objectives, there can be made a basic foundation which can help the hobbies of the association and additionally the ones of the workers (Scott and Bruce, 2004). Ideally arousing the employee motivation is a factor that should be initiated in an organization to increase their commitment and retain them for a longer period.

Performance management: it means "the continuous process of identifying, measuring, and developing the performance of individuals and teams and aligning their performance with the organization's goals" Glendinning, (2007). Risher (2005) mentioned to the performance management's six basic elements as follows: direction sharing, goal alignment, ongoing performance monitoring, coaching and development support, recognition and rewards, and ongoing feedback.

\subsection{Literature Review}

In a study conducted by Balkin and Gomez-Mejia (1990) on the topic of management and organizational theories. The data was collected through (150) questionnaires distributed to randomised organizations within the U.S. The results suggested that management and organizational theories incorporates changes which focus on organizations' adaptation to human resource management activities and organizational competitiveness. Human resources and human resource management activities were found to be jointly serving as a platform upon which all knowledge creations, skills, and rapid diffusion of new technology are practiced. If strategically utilized, this platform will yield a successful human resource management, which in turn results to the success in organizational performance. The results further affirmed that there exists a strong link between organizational strategic planning and human resource management activities.

A study by Arthur (1994) aimed at determine the influence of human resource departments on the performance levels of organizations affirmed that an efficient performance of human resource department aids the determination of the performance level within an organization. The study collected data from middle-scale organizations, which had recently formed new human resource departments. The study results indicated that best practices in human resource management activities will ensure the business compete fairly in the global business arena, and this was only possible if strategic plans were put in place. Through the strategic planning, the recruitment of employees, career planning as well as the retention exercise becomes so easy, a factor that has contributed to high productivity in various organizations. The concept also makes it possible to determine the performance appraisal among the human resource management activities so as to ascertain the efficacy of the staff in their various responsibilities. Cases of human resource planning incorporate making an association structure, assessing the utilization of contractual workers versus workers, looking into an organization's advantages arrangement, and deciding the arrival on the 
venture of a wellbeing program or making approaches and methodology to keep a business agreeable with all its work and livelihood commitments.

In a study organized by Jackson and Schuler (1995) to test the impacts of organizational strategies on human resource management further supported that sstrategic planning helps in determining how many employees will be required by the organization to perform in the nearest future. Their study was based on data collected through both interviews and questionnaires amongst randomly chosen employees. In essence, the recruitment of workers in a given firm should be given a practical approach if profitability is to be witnessed. Therefore, managers must acknowledge the fact that conducive working environment is fundamental and a factor that boosts the morale of the workers in a business firm. Having a desirable strategy on how to put in place, the friendly working condition will indeed lead to higher performance in the field. Since the human activities are factors that should be induced to produce the desired outcome, one should concentrate on the top notch priorities that will boost the morale of the workers.

In a study conducted by Delaney and Huselid (1996) to examine the influence of human resources and related activities on the general organizational performance recommended that companies or organizations are advised to come up with mission statements that elaborate their core objectives, strategies, future directions and profitability targets in their activities. This was a study conducted on different employees from different job levels, where data was collected through oral interviews. Further results proposed that organizations/companies ought to create certain functional strategies, including marketing strategies and financial management in a way that defines their resource allocations in order to realize their goals. The exercise of strategic planning would thereby assist managers in the analysis of relevant internal environmental conditions. This will be helpful in realising the anticipated opportunities, possible threats, hence work to improve the organizational performance through imposing the most relevant strategic plans and human resources.

A study by Narasimha (2000) to review the impacts of strategic human activities and human resource management on organizational performance affirmed that there is a positive link between the extent of strategic plan formality and organizational performance since greater emphasis shall be on the improvement of the quality of strategic decision-making processes. These may include the development of distinctive competence, goal formulation, human resource deployment, authority relationship determinations, and implementation monitoring. This was a survey conducted to determine the influence of human behaviours, traits, and activities on the general organizational management and success through open ended questionnaires. The results further elicited that strategic planning may impact human resource management activities through influencing employees' motivation system, work organization, as well as skills, ability and knowledge enhancement. It commonly becomes impossible to plan effectively when the business environment is presenting constant changing parameters.

In a study organized by Dessler (2011) on the concepts of strategic planning and organizational performance, strategic planning comprises of three primary elements that have boosted the achievement of the organizations by making their visions and missions attainable. The study results revealed these features to entail the strategic analysis, goals and choices. This was a quantitative study conducted to confirm the relationships between strategic planning and organizational success. Notably, the strategic analysis focused towards setting the organization or enterprises direction regarding its mission, vision, and goals. The results also revealed this concept to depict the fact that a company's strategic intent should be articulated and channelled towards the better knowledge of the business environment. The study also showed that strategic choices involve establishing, evaluating and selection of the outstanding strategy.

According to Prasad (2012), human resource strategy emphasizes on how organizations ought to manage their staff in order to attain their corporate objectives. In his study, he argues that organizations with outstanding mission statement and corporate strategies are assumed to have developed relevant human resource strategies in addressing their issues and strategic implementations. This was a cross sectional study, which incorporated both qualitative and quantitative data analysis on the topic of "human resource strategies and organizational performance." The results indicated that the strategy pursued by an organization is directly associated with the needs for human resource implementations. Here, the skills must be acquired alongside relevant knowledge in order to come up with a relevant control system that aims at achieving the organization's goals.

The study conducted by Noe (2013) to determine the effects of strategic planning on human resource management defined strategic planning to be comprised of a set of underlying approaches or processes that are geared towards establishing or manipulating the existing situation in order to give a desirable outcome. The data collected from the study through interviews suggested that strategic planning can be characterized as the procedure of utilizing efficient 
criteria and thorough examination to formulate, actualize and control system and formally archive organization's desires. Results from the study affirmed that strategic planning is one of the key tools for finding the future for a given organization as well as the best path to attain a given goal. According to Noe (2013), it is important to note that strategic planning depicts the process that most firms comply with in their attempts to define their directions and decision-making, which relates to allocation of the available resources.

Finally, the study of Niehaus et al (2013) conducted a study whose results confirmed that modern civilization, globalization, coupled with the introduction of new technologies within the firms/organizations have currently resulted into conspicuous changes within the contemporary business landscape. Their study was based on the influence of strategic planning on organizational performance, conducted through a survey using questionnaires. One of their major results/outcome suggested that one of the best ways through which organizations endeavour to uphold their competiveness within the changing organizational landscape is through the strategic management of human resources.

What distinguishes this study from previous studies that its deal with Saudi Banks, which have not been investigated as the best of the researchers' knowledge; in addition the current study covered a number of hypotheses that have not been previously considered, at least empirically.

\section{Study's Methodology}

This study conducted descriptive and analytical study design on the relationship between human resources management activities and the practice of strategic planning in Saudi banks. Specifically, the researcher collected the necessary data and information that will use in the entire study. Primary and secondary data were used for the current study. Primary data were collected through questionnaire. Secondary data (theoretical feedback and previous studies) were collected through different sources of books, scientific journals, and the internet. In more details, in this section the authors outline the study approach, the study process, the selection of the sample, measuring instruments, validity the tool of the study, reliability, statistical methods used, limitations of the study, and ethical considerations.

\subsection{Study Approach}

This study includes quantitative techniques. Quantitative study techniques employ collect numerical data and use statistical analysis to arrive at valuable conclusions.

\subsection{Study Process}

The researchers came in touch with participants and asked them to participate in the study after explaining the nature and the scope of the study.

\subsection{Population and Sampling Technique}

The unit analysis is individual level. Table 1 shows the population of this study consist of all the senior level employees in human resource departments of the banks working in Saudi Arabia. The number of employees was obtained from the human resource department in six different banks (Al Rajhi Bank, Saudi Investment Bank, National Commercial Bank, Riyad Bank, SABB, and Saudi Hollandi Bank). Currently, the number of employees at each bank are as follows:

Table 1. The number of senior level employees at Saudi banks

\begin{tabular}{ccc}
\hline Bank & Population & Sample \\
\hline Al Rajhi Bank & 126 & 79 \\
Saudi Investment Bank & 32 & 21 \\
National Commercial Bank & 108 & 61 \\
Riyad Bank & 24 & 13 \\
SABB & 22 & 14 \\
Saudi Hollandi Bank & 19 & 12 \\
\hline Total & $\mathbf{3 3 1}$ & $\mathbf{2 0 0}$ \\
\hline
\end{tabular}

Out of this number, a total of (200) senior level employees are selected at random using simple random sampling to represent the senior level employees of those banks. 


\subsection{Measuring Instruments}

Data was collected by means of a questionnaire designed by the researchers. It consisted of forty (40) items, which were designed according to (likert scale): strongly disagree, disagree, don't know, agree, strongly agree, and given the weights $(1,2,3,4$, and 5). The higher the mean, indicates to higher degree of consent on the item. As the questionnaire was divided into three parts as follows:

Part One: it included a number of items that aim to know the personal data of the sample members (5 items), they are: gender, age, years of experience, educational qualification, and job title.

Part Two: it included a number of items that aim to measure the human resources management activities from the perspective of the sample members ( 34 items). This items has been divided into a set of items, namely: job analysis: measured by items (1-4), human resources planning: measured by items (5-9), recruitment: measured by items (10-14), selection: measured by items (15-19), training and development: measured by items (20-24), motivation: measured by items (25-29) and performance management: measured by items (30-34). The (34) items were taken from Aldmour's study (2008).

Part Three: it included a number of items that aim to measure the strategic planning from the perspective of the sample members (6 items: 35-40). The (6) items were taken from Aldmour's study (2008).

\subsection{Validity the Tool of the Study}

To testify the validity of the study, a number of steps were taken: First: a number of questionnaires were distributed to a number of referees, of professors and specialists in human resources management to assess the questions for accuracy. Based on their recommendations and comments, many modifications were done; some items were deleted, new items were added and other items were rephrased until the questionnaire reached its final form. Second: the statistician reviewed the questionnaire in terms of its format, layout, and whether the type of questions were suitable for statistical analysis. Third: a pilot study with fifty participants was conducted to further ensure the validity and reliability of the questionnaire.

\subsection{Reliability}

To examine the harmony of questionnaire statements, the Cronbach's alpha coefficient was used to calculate the internal consistency of the measuring scales the Cronbach's alpha for human resources activates dimensions and the practice of strategic planning dimensions. The Cronbach's alpha for human resources activates dimensions is $(0.83)$. The Cronbach's alpha for the practice of strategic planning dimensions is $(0.89)$. This result indicates that the reliability coefficient for all dimensions is not less than $(0.60)$. This also means that the study tool is consistent and valid for the purposes of statistical analysis and scientific research. The results are reported in Table 2.

Table 2. The Cronbach's Alpha coefficient values for variables for this study

\begin{tabular}{ccc}
\hline Variables & No. of Items & Alpha \\
\hline Human resources activates & 34 & 0.83 \\
The practice of strategic planning & 6 & 0.89 \\
\hline
\end{tabular}

\subsection{Statistical Methods Used}

The following statistical methods were used for statement attributes of the study sample and for examining the hypotheses of the study: frequencies, percentages, means, standard deviation, and multiple linear regression analysis.

\subsection{Limitations of the Study}

As is the case with other research studies, the design of the current study is subject to a numbers of limitations that need to be considered. First, this study is a pioneer investigation in the relationship human resources management activities and strategic planning in Saudi Arabia. Thus further research is needed to assess the validity of the findings in a wider context. Second, the researchers chose to study employees only in the private sectors, rather than including for example the health sector or the military. The reasons for this delimitation are the private sector is a very important sector for applying the Saudization policy. Also, the government has declared its intention to privatise some of the public sector activities (Ministry of Economy and Planning, 2015-2019). Third, this study was applied in Riyadh city because (1) the majority of the private companies are located in this city (2) constraints of time in data 
collection and the limitation of financial resources. It is difficult to cover the vast area of Saudi Arabia. Hence the results can only be generalised with caution. Fourth, because of the conservative nature of Saudi society, and because the majority of employees in bank sectors are males, female employees were not included in the research sample in this study. The sample involved males only.

\subsection{Ethical Considerations}

The present study was subject to some ethical issues. All participants reported their acceptance regarding their participation in the study. At the same time, they were free to withdraw from it at any time without any reason. Next to this, participants were informed regarding the purpose of the study, neither their names nor the name of their organizations will be revealed in the study. Also, they were promised that their responses will not be seen by their employers and will be used for the purpose of scientific study only.

\section{Data Analysis of Results Interpretation of Results}

This section relates the findings obtained through the main instrument of this study, namely the quantitative analysis of the data collected from the questionnaire. This section is structured into two main parts. The first part is the section that analyse the sample of the study. The second section touches on the testing of the hypotheses with interpretation of results.

\subsection{The Sample of the Study}

The sample of the study was consisted of (200) employers from both genders who work in "Saudi banks". Table 3 shows distributing the individuals of the sample according to the variable of gender. Table 3 also shows that number of males was (138) and the percentage was (69\%), whereas the number of females was (62) and the percentage was $(31 \%)$.

Table 3. Distributing the individuals of the sample according to variable of gender

\begin{tabular}{lll}
\hline Gender & Frequency & Percentage \\
\hline Male & 138 & $69 \%$ \\
\hline Female & 62 & $31 \%$ \\
\hline Total & 200 & $100 \%$ \\
\hline
\end{tabular}

Table 4 shows the percentage for distributing the individuals of the study according to variable of age. The highest percentage was $(41 \%)$ for the category $(30-40)$ years. Whereas the lowest percentage was $(1 \%)$ for the category $(61$ years and above) years.

Table 4. Distributing the individuals of the sample according to the variable of age

\begin{tabular}{|c|c|c|}
\hline Age & Frequency & Percentage \\
\hline Less than 30 years & 28 & $14 \%$ \\
\hline From 30 to less than 40 & 82 & $41 \%$ \\
\hline From 40 to less than $50 \mathrm{~s}$ & 57 & $28.5 \%$ \\
\hline From 50 to less than 60 & 31 & $15.1 \%$ \\
\hline 61 years and above & 2 & $1 \%$ \\
\hline Total & 200 & $100 \%$ \\
\hline
\end{tabular}

Table 5 shows the percentage for distributing the individuals of the study according to variable of years of experience. The highest percentage was $(38.57 \%)$ for the category (from 11 to less than 15 years). Whereas the lowest percentage was $(6 \%)$ for the category (less than 5 years) years. 
Table 5. Distributing the individuals of the study according to years of experience

\begin{tabular}{|c|c|c|}
\hline Years of experience & Frequency & Percentage \\
\hline Less than 5 years & 12 & $6 \%$ \\
\hline From 5 to less than 10 years & 38 & $19 \%$ \\
\hline From 11 to less than 15 years & 77 & $38.5 \%$ \\
\hline From 16 to less than 20 years & 53 & $26.5 \%$ \\
\hline From 21 years and more & 20 & $10 \%$ \\
\hline Total & 200 & $100 \%$ \\
\hline
\end{tabular}

Table 6 shows the percentage for distributing the individuals of the study according to variable of educational qualification. The highest percentage was (43\%) for the category (postgraduate study). Whereas the lowest percentage was $(5.5 \%)$ for the category (high school or less).

Table 6. Distributing the individuals of the study according to educational qualification

\begin{tabular}{|c|c|c|}
\hline Educational qualification & Frequency & Percentage \\
\hline High school or less & 11 & $5.5 \%$ \\
\hline Diploma & 25 & $12.5 \%$ \\
\hline Bachelor & 78 & $37 \%$ \\
\hline Postgraduate study & 86 & $43 \%$ \\
\hline Total & 200 & $100 \%$ \\
\hline
\end{tabular}

Table 7 shows the percentage for distributing the individuals of the study according to variable of job title. The highest percentage was $(48.5 \%)$ for the category (department manager). Whereas the lowest percentage was $(2.5 \%)$ for the category (general manager).

Table 7. Distributing the individuals of the study according to job title

\begin{tabular}{|c|c|c|}
\hline Job title & Frequency & Percentage \\
\hline Supervisor & 65 & $32.5 \%$ \\
\hline Department manager & 97 & $48.5 \%$ \\
\hline Assistant general manager & 33 & $16.5 \%$ \\
\hline General manager & 5 & $2.5 \%$ \\
\hline Total & 200 & $100 \%$ \\
\hline
\end{tabular}

\subsection{Hypotheses Testing}

This section examines the proposed hypotheses, each of which represents some type of relationship between the main two variables of this study (human resource management activities and the practice of strategic planning). Simple linear regression was adapted for testing the hypotheses. The decision to accept or reject the hypothesis was relying on the following rules: accept the null hypothesis if the significance is lower than 0.05 . Reject the null hypothesis if the significance is higher than 0.05 .

$\mathbf{H}_{1}$ : There is no statistically significant correlation between human resource management activities and the practice of strategic planning in Saudi banks.

Under this main hypothesis, there are a variety of sub- hypotheses:

$\mathbf{H}_{1-1}$ : There is no statistically significant correlation between job analysis and the practice of strategic planning in the human resource department at Saudi Banks. 
To test this hypothesis, linear regression was used and the following statistical analysis applied:

Table 8 . The results of the relationship between job analysis and the practice of strategic planning

\begin{tabular}{lllll}
\hline $\begin{array}{l}\text { Correlation } \\
\text { Coefficient }\end{array}$ & R 2 & F & Significance & Result of Ho \\
\hline 0.61 & $37 \%$ & 82.61 & 0.043 & Reject \\
\hline
\end{tabular}

Table 8 shows that the correlation coefficient is $(0.061)$. The variation ratio explained by job analysis (independent variable) of the variation in the practice of strategic planning (dependent variable) was (37\%), the $\mathrm{F}$ value is $(82.61)$, the significance level is (0.043). Since the significance level is lower than (0.05), we do reject the null hypothesis and accept the alternative hypothesis which states: there is statistically significant correlation between job analysis and the practice of strategic planning in the human resource department at Saudi Banks.

A possible explanation for this result may be, human resources employees collect the following information via the job analysis: work activities, human behaviours, machines, tools, equipment, work aids, performance standards, job context, and human requirements. In the Saudi banks, the human resources specialists apply the policy of job analysis in a manner that is consistent with the bank's strategic plan of job analysis.

$\mathbf{H}_{1-2}$ : There is no statistically significant correlation between human resource planning and the practice of strategic planning in the human resource department at Saudi Banks.

To test this hypothesis, linear regression was used and the following statistical analysis applied:

Table 9. The results of the relationship between human resource planning and the practice of strategic planning

\begin{tabular}{lllll}
\hline $\begin{array}{l}\text { Correlation } \\
\text { Coefficient }\end{array}$ & R 2 & F & Significance & Result of Ho \\
\hline 0.47 & $62 \%$ & 92.27 & 0.00 & Reject \\
\hline
\end{tabular}

Table 9 shows that the correlation coefficient is (0.47). The variation ratio explained by human resources planning (independent variable) of the variation in the practice of strategic planning (dependent variable) was $(62 \%)$, the $\mathrm{F}$ value is (92.27), the significance level is (0.00). Since the significance level is lower than (0.05), we do reject the null hypothesis and accept the alternative hypothesis which states: there is statistically significant correlation between human resources planning and the practice of strategic planning in the human resource department at Saudi Banks.

A possible explanation for this result may be, human resources management decide that positions the bank will have to fill and how to fill these position. In the Saudi banks, the human resources specialists apply the policy of human resources planning in a manner that is consistent with workforce/personnel planning and forecasting.

$\mathbf{H}_{1-3}$ : There is no statistically significant correlation between recruitment and the practice of strategic planning in the human resource department at Saudi Banks.

To test this hypothesis, linear regression was used and the following statistical analysis applied:

Table 10. The results of the relationship between recruitment and the practice of strategic planning

\begin{tabular}{lllll}
\hline $\begin{array}{l}\text { Correlation } \\
\text { Coefficient }\end{array}$ & R 2 & F & Significance & Result of H0 \\
\hline 0.75 & $55 \%$ & 111.2 & 0.00 & Reject \\
\hline
\end{tabular}


Table 10 shows that the correlation coefficient is $(0.75)$. The variation ratio explained by recruiting (independent variable) of the variation in the practice of strategic planning (dependent variable) was (55\%), the $\mathrm{F}$ value is (111.2), the significance level is $(0.00)$. Since the significance level is lower than $(0.05)$, we do reject the null hypothesis and accept the alternative hypothesis which states: there is statistically significant correlation between recruiting and the practice of strategic planning in the human resource department at Saudi Banks.

A possible explanation for this result may be, human resources management is attracting applicants for the bank's open positions. In the Saudi banks, the human resources specialists apply the policy of recruiting in a manner that is consistent with the bank's strategic plan of recruiting.

$\mathbf{H}_{1-4}$ : There is no statistically significant correlation between selection and the practice of strategic planning in the human resource department at Saudi Banks.

To test this hypothesis, linear regression was used and the following statistical analysis applied:

Table 11. The results of the relationship between selection and the practice of strategic planning

\begin{tabular}{lllll}
\hline $\begin{array}{l}\text { Correlation } \\
\text { Coefficient }\end{array}$ & R 2 & F & Significance & Result of Ho \\
\hline 0.62 & $44 \%$ & 97.2 & 0.00 & Reject \\
\hline
\end{tabular}

Table 11 shows that the correlation coefficient is (0.62). The variation ratio explained by selection (independent variable) of the variation in the practice of strategic planning (dependent variable) was (44\%), the $\mathrm{F}$ value is (97.2), the significance level is $(0.00)$. Since the significance level is lower than (0.05), we do reject the null hypothesis and accept the alternative hypothesis which states: there is statistically significant correlation between selection and the practice of strategic planning in the human resource department at Saudi Banks.

A possible explanation for this result may be, the employees selection process usually include advertising, reviewing, screening, interviewing, testing, and finally selecting the best available candidate. In the Saudi banks, the human resources specialists apply the policy of selection in a manner that is consistent with the bank's strategic plan of selection.

$\mathbf{H}_{1-5}$ : There is no statistically significant correlation between training and development and the practice of strategic planning in the human resource department at Saudi Banks.

To test this hypothesis, linear regression was used and the following statistical analysis applied:

Table 12. The results of the relationship between training and development and the practice of strategic planning

\begin{tabular}{lllll}
\hline $\begin{array}{l}\text { Correlation } \\
\text { Coefficient }\end{array}$ & R 2 & F & Significance & Result of Ho \\
\hline 0.52 & $26 \%$ & 66.3 & 0.00 & Reject \\
\hline
\end{tabular}

Table 12 shows that the correlation coefficient is $(0.52)$. The variation ratio explained by training and development (independent variable) of the variation in the practice of strategic planning (dependent variable) was $(26 \%)$, the $\mathrm{F}$ value is (66.3), the significance level is $(0.00)$. Since the significance level is lower than $(0.05)$, we do reject the null hypothesis and accept the alternative hypothesis which states: there is statistically significant correlation between training and development and the practice of strategic planning in the human resource department at Saudi Banks.

A possible explanation for this result may be, the employees training process usually entails teaching employees the basic skills they need to do their jobs in an effective way. In the Saudi banks, the human resources specialists apply the policy of training and development in a manner that is consistent with the bank's strategic plan of training and development. 
$\mathbf{H}_{1-6}$ : There is no statistically significant correlation between motivation and the practice of strategic planning in the human resource department at Saudi Banks.

To test this hypothesis, linear regression was used and the following statistical analysis applied:

Table 13. The results of the relationship between motivation and the practice of strategic planning

\begin{tabular}{lllll}
\hline $\begin{array}{l}\text { Correlation } \\
\text { Coefficient }\end{array}$ & R 2 & F & Significance & Result of H0 \\
\hline 0.27 & $14 \%$ & 16.52 & 0.009 & Reject \\
\hline
\end{tabular}

Table 13 shows that the correlation coefficient is $(0.26)$. The variation ratio explained by motivation (independent variable) of the variation in the practice of strategic planning (dependent variable) was (14\%), the $\mathrm{F}$ value is (16.52), the significance level is (0.009). Since the significance level is lower than (0.05), we do reject the null hypothesis and accept the alternative hypothesis which states: there is statistically significant correlation between motivation and the practice of strategic planning in the human resource department at Saudi Banks.

A possible explanation for this result may be, the human resources management design motivation system to encourage their employees to do their jobs in the most effective way. In the Saudi banks, the human resources specialists apply the policy of motivation in a manner that is consistent with the bank's strategic plan of motivation.

$\mathbf{H}_{1-7}$ : There is no statistically significant correlation between performance management and the practice of strategic planning in the human resource department at Saudi Banks.

To test this hypothesis, linear regression was used and the following statistical analysis applied:

Table 14. The results of the relationship between performance management and the practice of strategic planning

\begin{tabular}{lllll}
\hline $\begin{array}{l}\text { Correlation } \\
\text { Coefficient }\end{array}$ & R 2 & F & Significance & Result of H0 \\
\hline 0.71 & $52 \%$ & 105.84 & 0.00 & Reject \\
\hline
\end{tabular}

Table 14 shows that the correlation coefficient is $(0.71)$. The variation ratio explained by performance management (independent variable) of the variation in the practice of strategic planning (dependent variable) was (52\%), the $\mathrm{F}$ value is (105.84), the significance level is $(0.00)$. Since the significance level is lower than $(0.05)$, we do reject the null hypothesis and accept the alternative hypothesis which states: there is statistically significant correlation between performance management and the practice of strategic planning in the human resource department at Saudi Banks.

A possible explanation for this result may be, the human resources management mange and do the most important points related to performance management (some of these points are: face to face planning, set objective, and set development plan) then do the appraisal. In the Saudi banks, the human resources specialists apply the policy of performance management in a manner that is consistent with the bank's strategic plan of performance management.

$\mathbf{H}_{2}$ : There are no statistically significant differences in the impact of human resource management activities on the practice of strategic planning in Saudi Banks as related to each of the personal and functional variables (gender, age, educational qualification, job title, and years of experience). 


\section{Gender}

Table 15. The results of linear regression between human resource management activities and gender

\begin{tabular}{lllll}
$\begin{array}{l}\text { Non Linear Regression between human } \\
\text { resource management activities and gender }\end{array}$ & $\mathbf{T}$ & Significance & Result of H0 \\
\hline-0.228 & -1.693 & 0.492 & Accept \\
\hline
\end{tabular}

Table 15 shows that the T value is $(-1.693)$, the significance is $(0.492)$. Since the significance level is higher than $(\alpha$ $\leq 0.05)$, we do accept the null hypothesis. That's mean there are no significant differences statistically at the level of $(\alpha \leq 0.05)$ between the practice of human resource management activities and strategic planning in Saudi Banks attributed to gender variable.

Age

Table 16. The results of linear regression between human resource management activities and age

\begin{tabular}{llll}
\hline $\begin{array}{l}\text { Non Linear Regression between human resource } \\
\text { management activities and Age }\end{array}$ & $\mathbf{T}$ & Significance & Result of Ho \\
\hline-0.360 & -1.19 & 0.87 & Accept \\
\hline
\end{tabular}

Table 16 shows that the T value is (-1.19), the significance is $(0.87)$. Since the significance level is higher than $(\alpha \leq$ $0.05)$, we do accept the null hypothesis. That's mean there are no significant differences statistically at the level of $(\alpha$ $\leq 0.05$ ) between the practice of human resource management activities and strategic planning in Saudi Banks attributed to gender variable.

\section{Educational Qualification}

Table 17. The results of linear regression between human resource management activities and educational qualification

\begin{tabular}{lllll}
$\begin{array}{l}\text { Non Linear Regression between human resource } \\
\text { management activities and educational qualification }\end{array}$ & $\mathbf{T}$ & Significance & Result of H0 \\
\hline 0.35 & 0.88 & 0.481 & Accept \\
\hline
\end{tabular}

Table 17 shows that the $\mathrm{T}$ value is $(0.88)$, the significance is $(0.481)$. Since the significance level is higher than $(\alpha \leq$ $0.05)$, we do accept the null hypothesis. That's mean there are no significant differences statistically at the level of $(\alpha$ $\leq 0.05$ ) between the practice of human resource management activities and strategic planning in Saudi Banks attributed to gender variable.

\section{Job Title}

Table 18. The results of linear regression between human resource management activities and job title

\begin{tabular}{lllll}
\hline $\begin{array}{l}\text { Non Linear regression between human } \\
\text { resource management activities and job } \\
\text { title }\end{array}$ & $\mathbf{T}$ & Significance & Result of Ho \\
\hline 0.04 & 0.012 & 0.99 & Accept \\
\hline
\end{tabular}


Table 18 shows that the $\mathrm{T}$ value is $(0.012)$, the significance is $(0.99)$. Since the significance level is higher than $(\alpha \leq$ $0.05)$, we do accept the null hypothesis. That's mean there are no significant differences statistically at the level of $(\alpha$ $\leq 0.05$ ) between the practice of human resource management activities and strategic planning in Saudi Banks attributed to gender variable.

\section{Years of experience}

Table 19. The results of linear regression between human resource management activities and years of experience

\begin{tabular}{llll}
\hline $\begin{array}{l}\text { Non Linear Regression between human resource } \\
\text { management activities and years of experience }\end{array}$ & $\mathbf{T}$ & Significance & Result of Ho \\
\hline-.052 & -0.73 & 0.632 & Accept \\
\hline
\end{tabular}

Table 19 shows that the $\mathrm{T}$ value is $(-0.73)$, the significance is $(0.632)$. Since the significance level is higher than $(\alpha \leq$ $0.05)$, we do accept the null hypothesis. That's mean there are no significant differences statistically at the level of $(\alpha$ $\leq 0.05$ ) between the practice of human resource management activities and strategic planning in Saudi Banks attributed to gender variable.

Finally, as we noted there are no significant differences statistically at the level of $(\alpha \leq 0.05)$ between the practice of human resource management activities and strategic planning in Saudi Banks attributed to demographic variables. This result consistent with previous studies (Alafeef, 2005, Aldmour, 2008). A possible explanation for this result may be, all employees in human resources management have one goal and work together to execute human resources management activities in these banks regardless of their gender, age, educational qualification, and years of experience.

\section{Conclusion}

The objective of this study was to investigate the relationship between human resources activities and strategic planning in Saudi banks. The results of the study confirmed that human resources activities impacts positively and significantly on the strategic planning of the banks. The results unearth the fact that motivation and human resource planning activities are significantly associated with strategic planning but it is a week relationship. Lastly, it is generally argued that management's support in terms of motivation and human resource planning result in greater employee performance as the latter will lead to high productivity.

\section{Recommendations}

Based on the findings of this study, several recommendations are made hereunder:

1- Human resource management activities are affecting all aspect of the bank and it is one of most key success factors. Thereby, the banks should invest more in this area. All activities are having direct and indirect impact on each employee and on the practice of strategic planning. Every bank should have particular unit to insure and emphasise the importance their strategy and the alignments with other department.

2- The correlation between motivation and the practice of strategic planning is week. Therefore, the bank should be more cautious about this area. Motivating the employees in a systematic manner (financially or appreciation) will affect them positively by increase their productivity and performance, otherwise they will be dissatisfy or burnout.

3- Learning and development is one of the biggest challenges in the banking sector. By providing more high level courses to employees in the managerial level will directly affect the practice of strategic planning in a positive way. The output of such courses will increase the knowledge of the decision maker and will lead to more success in achieving the goals of the bank.

4- By enhancing the job analysis process, the tasks and the responsibilities of every member in the bank will be identified. This will help every employee to know clearly their rules within the strategy of the bank.

5- Human resource planning is highly impact on the strategic planning, that's why Saudi banks should maintain this strong relationship between human resource planning and the practice of their strategic planning. By maintaining this relationship, the bank will guarantee that their business strategy in human resource is aligned with the corporate strategy of the bank. 


\section{Areas for Further Study}

The findings of this study did not cover comprehensively all factors which discuss strategic planning in the Saudi Arabia work organizations. The study provides other areas for the further research including:

- The relationship between human resources management activities and the practice of strategic planning: a public and private sector comparison in Saudi Arabia.

- The relationship between human resources management activities and the practice of strategic planning: a male and female comparison in Saudi Arabia.

\section{References}

Alafeef, A. (2005). The Factors That Affect Strategic Planning in the Jordan Public Sector: A Field Study, Unpublished Master's thesis, The Jordan University, Amman, Jordan.

Al-Domour, M. (2008). The Status-Quo of Strategic Planning of Human Resources in the Public Sector in the Hashemite Kingdom of Jordan. Unpublished Doctoral's thesis, The Arabic Academic for Finance Sciences, Amman, Jordan.

Arthur, J. (1994). Effects of Human Resource Systems on Manufacturing Performance and Turnover. Academy of Management Journal, 37(3), 670-687. https:/doi.org/10.2307/256705

Balkin, D. B., \& Gomez-Mejia, L. R. (1990). Matching Compensation and Organizational Strategies. Strategic Management Journal, 11(2), 153-169. https:/doi.org/10.1002/smj.4250110207

Bryson, J. (2010). The Future of Public and Nonprofit Strategic Planning in the United States. Public Administration Review, 70, 255-267. https:/doi.org/10.1111/j.1540-6210.2010.02285.x

Bryson, M. J. (2004). Strategic Planning for Public and Non-Profit Organizations. London: Jossey-Bass Publishers.

Delaney, J., \& Huselid, M. (1996). The Impact of Human Resource Management Practices on Perceptions of Organizational Performance. Academy of Management Journal, 39(4), 149-169. https:/doi.org/10.2307/256718

Dessler, G. (2011). A Framework for Human Resource Management. Pearson Education India.

Dessler, G. (2015). Human Resources Management (14 ${ }^{\text {th }}$ ed.). Pearson.

Glendinning, P. (2007). Performance Management: Pariah or Messiah, Public Personnel management, 31(2), 161-178. https:/doi.org/10.1177/009102600203100203

Ieva, N., Roman, P., \& Tatjana, M. (2012). Strategic Planning and Management in Public and Private Sector Organization in Europe: A Comparative Analysis and Opportunities for Improvement. European Integration Studies, 6.

Jackson, S., \& Schuler, R. (1995). Understanding Human Resource Management in the Context of Organizations and Their Environments. Annual Review of Psychology, 46(4), 237-264. https:/doi.org/10.1146/annurev.ps.46.020195.001321

Jehads, S., \& Naseem, T. (2011). Strategic Planning and Corporation Performance Relationship in Small Business Firms: Evidence from a Middle East Country Context. International Journal of Business and Management, $6(8)$.

Ministry of Economy and Planning, Saudi Arabia. (2016).Retrieved from http://www.mep.gov.sa

Narasimha, S. (2000). Organizational Knowledge, Human Resource Management, and Sustained Competitive Advantage: Toward a Framework. Competitiveness Review, 10(1), 123-135. https:/doi.org/10.1108/eb046392

Niehaus, R. J., Price, K. F., \& Human Resource Planning Society. (2013). Bottom Line Results From Strategic Human Resource Planning. New York: Plenum Press.

Noe, R. A. (2013). Human Resource Management: Gaining a Competitive Advantage. New York: McGraw-Hill/Irwin.

Prasad, K. (2012). Strategic Human Resource Development: Concepts and Practices. New Delhi: PHI Learning.

Risher, H. (2005). Getting Serious about Performance Management, Compensation and Benefits Review. November/December, Page 19. https:/doi.org/10.1177/088636870503700601

Sims, R. R. (2002). Organizational Success through Effective Human Resources Management. Westport, Ct: Quorum Books. 